\title{
Rotavirus infeksiyonuna bağlı seyrek görülen bir tutulum: Akut pankreatit
}

\author{
H. Haldun Emiroğlu \\ Selçuk Üniversitesi Tıp Fakültesi, Çocuk Sağığı ve Hastalıkları Anabilim Dalı, Çocuk Gastroenterolojisi Bilim Dalı, Konya, Turkey
}

Sayın Editor,

Oya Balcı ve ark.nın ${ }^{[1]}$ Çağdaş Tıp Dergisi'nin 2016 yılı üçüncü sayısında (Çağdaş Tıp Dergisi 2016;6(3);231-233) yayımlanan "Rufinamide Kullanımı Sonrası Gelişen Akut Pankreatit: Olgu Sunumu" başlıklı olgu sunumunu ilgi ile okudum. Bu makale, akut pankreatitin antiepileptik ilaçlardan biri olan rufinamide bağlı da gelişebileceğini vurgulaması yönüyle değerli bir çalışmadır. Bizim de Selçuk Üniversitesi Tıp Fakültesi Çocuk Sağlığı ve Hastalıkları Anabilim Dalı Çocuk Gastroenteroloji, Hepatoloji ve Beslenme Birimi'nde daha önce izlediğimiz rotavirüs enfeksiyonuna bağlı bir akut pankreatit olgumuzu, akut rotavirüs gastroenteriti tablosunda başvuran hastalarda seyrek rastlansa da akut pankreatit yönünden dikkatli olunması gereğini vurgulama amacıyla özetlemek istiyorum.

Yaklaşık 10 gündür devam eden karın ağrısı, inatçı kusma ve şiddetli ishal (bol sulu, 15-16 kez/gün) yakınmaları ile yatırılan 10 yaşındaki erkek hastanın öyküsünden özgeçmiş ve soygeçmişi ile ilgili herhangi bir özellik bulunmadığı, tarafımıza başvurusundan önce herhangi bir ilaç kullanmadığı öğrenildi. Fizik muayenede palpasyonla karın muayenesinde yaygın hassasiyet bulunan hastanın dışkı incelemesinde rotavirus antijeni pozitif saptanırken tam kan sayımı, eritrosit sedimantasyon hızı, tam idrar incelemesi, CRP ve kan biyokimyası (glikoz, üre, total protein, albumin, kreatinin, elektrolitler, ürik asit, LDH, AST, ALT, GGT, ALP, bilirübinler, lipaz ve amilaz) normal olarak değerlendirildi. Radyolojik incelemede karın ultrasonografisinde (USG) patolojik bir bulguya rastlanmadı. Rotavirüs gastroenteriti tedavisine yönelik parenteral sıvı destek tedavisi ile izlenirken tedavinin üçüncü günü karın ağrısının artması üzerine yapılan karın USG incelemesi normal bulunmakla birlikte kan biyokimyasında serum amilaz ve lipaz düzeylerinin normalin üst sınırına göre yaklaşık 3 katı kadar yükselmiş olduğu (lipaz, 201 U/L; normal değerler, 7-78 U/L) dikkati çekti. Akut pankreatit ön tanısı ile oral beslenme kesilerek nazogastrik dekompresyon ve parenteral beslenme desteği başlandı. Hastaneye yatışının 5 . günü serum lipaz düzeyi normalin üst sınııının yaklaşık 14 katı düzeyine (1086 U/L) ulaşması üzerine tipik klinik bulgu (kemer tarzında sırta doğru yayılan karın ağrısı semptomu), normalin üst sınırına göre 3 katından daha yüksek pankreas enzim düzeyleri ve karın USG incelemesinde pankreasta heterojen görünüm saptanmasına dayanarak ${ }^{[2]}$ akut pankreatit tanısı konuldu. Pankreatik sekresyonları azalttığı için akut pankreatit tedavisinde kullanımı önerilen ${ }^{[3,4]}$ oktreotid infüzyon tedavisi $(1 \mu \mathrm{g} / \mathrm{kg} /$ saat x 3 gün $+0.5 \mu \mathrm{g} / \mathrm{kg} / \mathrm{saat} \times 4 \mathrm{gün}$ ) başlandı. Akut pankreatit etyolojisine yönelik olarak yapılan kan biyokimya incelemesinde hipertrigliseridemi veya hiperkalsemi bulgusu saptanmadığı gibi MRCP görüntülemede anatomik ve viral serolojik incelemelerde de rotavirüs enfeksiyonu dışında altta yatan başka herhangi bir neden bulunamadı. Tedavi başlandıktan sonra 7 gün içinde karın ağrısı semptomu azalarak düzelen ve yüksek pankreas enzim düzeyleri gerileyerek normal sınırlara dönen hasta oral beslenmeye geçildikten sonra da tablonun tekrarlamaması üzerine kontrole çağrılarak taburcu edildi.

Rotavirüs çocuklarda akut gastroenterite yol açabilen en sık etiyolojik nedenlerden olmakla birlikte literatürde rotavirüse bağIı menengoensefalit veya pankreatit gibi diğer organların enfeksiyonları da bildirilmiştir. ${ }^{[5,6]}$ Akut gastroenteritli hastalarda amilaz yüksekliği görülebilmektedir. ${ }^{[7]}$ Ancak hastamızda lipaz

\section{Tablo 1. Akut pankreatit tanı kriterleri ${ }^{[2]}$}

\section{Aşağıdaki 3 kriterden en az 2'sinin bulunması}

1. Akut pankreatit ile uyumlu karın ağrısı

2. Serum amilaz ve/veya lipaz düzeylerinin normalin üst sınırına göre 3 katından daha yüksek bulunması

3. Radyolojik incelemelerde (ultrasonografi, manyetik rezonans görüntüleme veya bilgisayarlı tomografi) pankreatiti destekleyen bulguların saptanması

Corresponding (illetişim): H. Haldun Emiroğlu, Selçuk Üniv. Tıp Fak., Çocuk Sağlığı ve Hast. ABD, Çocuk Gastroenterolojisi BD, Konya, Turkey E-mail (E-posta): haldunemiroglu@gmail.com 
düzeyinin de normalin üst sınırına göre 3 katından daha yüksek bulunması, radyolojik incelemede (USG) pankreatiti destekleyen pankreasta heterojen görünüm saptanması ve akut pankreatit ile uyumlu karın ağrısı olduğundan uluslararası tanı kriterlerine ${ }^{[2]}$ göre akut pankreatit tanısı konulmuştur (Tablo 1).

Ayrıca, rotavirüs enfeksiyonuna bağlı akut pankreatit tanısı için etiyolojide rolü olabilen tüm diğer (enfeksiyöz, obstrüktif, metabolik, otoimmün, travmatik) nedenler de dışlanmıştır.

Sonuç olarak seyrek görülmekle birlikte rotavirüs infeksiyonuna bağlı akut pankreatit tablosu gelişebilmektedir. Rotavirüs gastroenteriti nedeni ile başvuran hastalarda karın ağrısının yalnızca gastroenterit tablosuna değil, aynı zamanda akut pankreatite bağlı olarak da gelişebileceğinin hatırlanması çok önemlidir.

Çıkar çatışması: Bildirilmemiştir.

\section{Kaynaklar}

1. Balcı O, Sezer T. Çağdaş Tıp Dergisi 2016;6:231-3.
2. Morinville VD, Husain SZ, Bai H, Barth B, Alhosh R, Durie PR, et al. Definitions of pediatric pancreatitis and survey of current clinical practices: report from Insppire (International Study Group Of Pediatric Pancreatitis: In Search For A Cure). J Pediatr Gastroenterol Nutr 2012;55:261-5.

3. Wang R, Yang F, Wu H, Wang Y, Huang Z, Hu B, et al. High-dose versus low-dose octreotide in the treatment of acute pancreatitis: a randomized controlled trial. Peptides 2013;40:57-64.

4. Suzuki M, Sai JK, Shimizu T. Acute pancreatitis in children and adolescents. World J Gastrointest Pathophysiol 2014;5:41626.

5. Dickey M, Jamison L, Michaud L, Care M, Bernstein DI, Staat MA. Rotavirus meningoencephalitis in a previously healthy child and a review of the literature. Pediatr Infect Dis J 2009;28:318-21.

6. Basturk A, Artan R, Yilmaz A. Rotavirus gastroenteritis and a rare case accompanying acute pancreatitis. Prz Gastroenterol 2017;12:68-9.

7. Tositti G, Fabris P, Barnes E, Furlan F, Franzetti M, Stecca C, et al. Pancreatic hyperamylasemia during acute gastroenteritis: incidence and clinical relevance. BMC Infect Dis 2001;1:18. 